\title{
PENGEMBANGAN E-LEARNING DENGAN PENDEKATAN TEORI KOGNITIF MULTIMEDIA PEMBELAJARAN DI JURUSAN TKJ SMK MUHAMMADIYAH 2 YOGYAKARTA
}

\author{
1)Dyah Ayu Kusumaningrum, 2)Eko Marpanaji \\ 1,2)Universitas Negeri Yogyakarta \\ 1)azuqie89@gmail.com, 2)eko@uny.ac.id
}

\begin{abstract}
Abstrak
Tujuan penelitian ini adalah mengembangkan, mengetahui kelayakan, dan mengetahui keefektifan implementasi e-learning dengan pendekatan teori belajar kogntif multimedia pembelajaran di jurusan Teknik Komputer dan Jaringan (TKJ) SMK Muhammadiyah 2 Yogyakarta. Metode yang digunakan pada penelitian ini adalah R\&D, yang meliputi empat tahap, yaitu: planning, design, development, dan summative evaluation. Hasil pengembangan produk e-learning berupa manajemen pembelajaran online dengan software aplikasi moodle versi 2.4 dengan alamat alamat http://etkj.web.id. Kelayakan produk e-learning pada aspek media mendapatkan nilai 3.88 (kategori baik), pada aspek materi mendapatkan nilai 3.88 (kategori baik), dan aspek respon siswa mendapatkan nilai 3.64 (kategori baik). E-learning dengan pendekatan teori kognitif multimedia pembelajaran efektif meningkatkan hasil belajar siswa.
\end{abstract}

Kata kunci: e-learning, kognitif multimedia pembelajaran

\section{DEVELOPING E-LEARNING \\ WITH COGNITIVE MULTIMEDIA FOR LEARNING APPROACH AT THE DEPARTMENT OF TKJ SMK MUHAMMADIYAH 2 YOGYAKARTA}

\author{
1)Dyah Ayu Kusumaningrum, 2)Eko Marpanaji \\ 1,2) universitas negeri yogyakarta \\ 1)azuqie89@gmail.com, 2)eko@uny.ac.id
}

\begin{abstract}
This research aims to develop, observe feasibility, and observe the effectiveness of the implementation of e-learning using cognitive multimedia for learning theory approach at the Department of Computer and Network Technology of SMK Muhammadiyah 2 Yogyakarta. This research was a research and development were four phases, including: planning, design, development, dan summative evaluation. The results of the develop of the e-learning product is the online learning model system created with moodle applications software version 2.4 with the address http://etkj.web.id. The appropriateness of the product in the media aspects gets a score of 3.88 (in the good category), in the material aspect it gets a score of 3.88 (in the good category), and in the students' responses aspect it gets a score of 3.64 (in the good category). Learning effectiveness Computer Engineering and Networks by using e-learning can be shown to significantly improve student learning outcomes.
\end{abstract}

Keywords: e-learning, cognitive multimedia for learning 


\section{Pendahuluan}

Kemajuan teknologi ilmu pengetahuan dan teknologi (IPTEK) mengakibatkan perubahan dan pertumbuhan kehidupan kearah yang lebih kompleks. Perubahan dan pertumbuhan tersebut menimbulkan kebutuhan, tuntutan dan inovasi baru yang tidak dapat diramalkan sebelumnya, sehingga perlu adanya penerapan ilmu pengetahuan dan teknologi (IPTEK) di bidang pendidikan.

Internet merupakan suatu bentuk kemajuan teknologi yang sedang populer saat ini. Internet memberikan kemudahan memperoleh informasi dengan mudah, efektif, dan efisien. Penggunaan fasilitas internet yang kurang efektif mendorong lahirnya suatu desain pembelajaran yang mampu melebihi pembelajaran yang ada saat ini. Fasilitas internet saat ini semestinya tidak hanya digunakan sebagai media hiburan dan media sosial semata, tetapi dapat digunakan untuk melakukan konsultasi masalah belajar, pemberian tugas, ujian, remediasi bagi siswa, dan menciptakan kegiatan layanan secara interaktif antara guru dan siswa dalam melakukan pengembangan bahan ajar bagi kepentingan pembelajaran.

Program studi Teknik Komputer dan Jaringan (TKJ) merupakan program studi yang baru didirikan dalam beberapa tahun terakhir di beberapa Sekolah Menengah Kejuruan di Indonesia. Program studi TKJ didirikan sebagai hasil perkembangan teknologi, dan bertujuan untuk membekali peserta didik dengan keterampilan, pengetahuan dan sikap agar kompeten dalam teknologi komputer. Kompetensi keahlian yang dipelajari siswa program keahlian ini adalah mengenai jaringan komputer dan aplikasinya dimana dasar ilmu yang dipelajarinya adalah menginstalasi perangkat komputer personal dan menginstall sistem operasi dan aplikasi; mendesain, menginstalasi, merawat dan maintenance perangkat jaringan lokal (Local Area Network), menginstalasi perangkat jaringan berbasis luas (Wide Area Network); dan mengadministrasi sistem operasi server jaringan. Proses belajar pada program keahlian TKJ terdiri dari teori dan praktek. SMK Muhammadiyah 2 Yogyakarta merupakan SMK yang memiliki program keahlian Teknik Komputer dan Jaringan. Program Keahlian TKJ di SMK Muhammadiyah 2 Yogyakarta didirikan bulan Juni 2004 dan pada tahun 2004/ 2005 pertama kalinya menerima siswa baru pada program keahlian ini. Program keahlian TKJ merupakan program yang berbasis teknologi dalam hal ini adalah pemanfaatan media komputer dan internet. Oleh karena itu, model pembelajaran yang diterapkan harus sesuai dengan karakteristik program studi ini. Model pembelajaran berbantuan komputer (Computer Based Instruction) dapat dijadikan sumber belajar yang tepat dalam kegiatan belajar mengajar. Pembelajaran berbasis komputer dan internet menawarkan berbagai keuntungan seperti kesempatan belajar yang lebih fleksibel tanpa terikat ruang dan waktu, memperkaya materi pembelajaran, menghidupkan proses pembelajaran, membuat proses pembelajaran lebih terbuka, meningkatkan efektifitas pembelajaran, serta mendukung peserta didik untuk belajar mandiri. Akan tetapi sekolah ini belum mempunyai media pembelajaran berbasis internet sebagai salah satu sumber belajar yang layak digunakan untuk meningkatkan efektivitas hasil belajar.

Berdasarkan hasil kuesioner analisis kebutuhan, media yang digunakan dalam pembelajaran masih kurang dibuktikan dengan $79.12 \%$ siswa menjawab media yang digunakan masih belum mecukupi dalam mendukung pembelajaran. Kecenderungan siswa dalam mengakses internet sangat tinggi, hal ini terlihat dari 33.33\% siswa sangat sering menggunakan internet, $66.67 \%$ siswa sering menggunakan internet, dan hanya $4.17 \%$ siswa yang jarang menggunakan internet. Banyak siswa yang menggunakan internet untuk memperoleh materi pelajaran, hal ini terlihat dari $54.17 \%$ siswa sangat sering mencari materi pembelajaran di internet, $33.33 \%$ siswa sering mencari materi pembelajaran di internet dan hanya $12.50 \%$ yang jarang mencari 
materi pembelajaran di internet. Perangkat yang digunakan untuk mengakses internet siswa adalah $100 \%$ menjawab komputer/ laptop, $79.17 \%$ menggunakan handphone, dan $8.33 \%$ menggunakan tablet. Sekolah mempunyai fasilitas dalam menyediakan akses internet diantaranya tersedianya wifi, dan lab komputer yang terhubung internet. Beberapa hambatan pembelajaran program keahlian TKJ di sekolah diantaranya adalah materi pelajaran disajikan dengan media yang sederhana sehingga siswa kurang termotivasi dalam belajar, kesulitan guru dalam mengelola kelas dan materi pelajaran yang berupa teori dan praktek yang banyak sehingga memakan waktu di kelas akan tetapi ruangan siswa untuk praktek terbatas sehingga waktu belajar di sekolah masih kurang. Hasil dari data tersebut menunjukan bahwa dibutuhkan strategi yang tepat untuk menyelesaikan permasalahan tersebut. Salah satu strategi untuk menyelesaikan permasalahan adalah penggunaan sarana telekomunikasi (internet, intranet, ekstranet) dan multimedia (grafis, audio, video) sebagai media dalam penyampaian materi dan interaksi antara pengajar (guru) dan pembelajar (siswa).

Inovasi yang sekarang mulai berkembang di lingkungan lembaga pendidikan adalah pemanfaatan komputer dengan menggunakan internet untuk menyampaikan materi pembelajaran. Pemanfaatan media berbantuan komputer dengan fasilitas internet yang selama ini dikembangkan dibeberapa sekolah kurang terorganisasi dengan baik, sehingga efektivitas, efisiensi penggunaan media kurang maksimal diterapkan. Salah satu solusi dari pengelolaan pemanfaatan media berbasis internet yang sering dikembangkan adalah pembelajaran berbasis e-learning. Pembelajaran e-learning merupakan pembelajaran dengan menggunakan jasa bantuan perangkat elektronik, khususnya perangkat komputer. Pembelajaran ini merupakan pembelajaran yang pelaksanaanya didukung oleh jasa teknologi seperti telepon, audio, videotape, transmisi satelit. Secara sederhana e-learning dapat dipahami se- bagai suatu proses pembelajaran yang memanfaatkan teknologi informasi berupa komputer yang dilengkapi dengan sarana telekomunikasi (internet, intranet, ekstranet) dan multimedia (grafis, audio, video) sebagai media utama dalam penyampaian materi dan interaksi antara pengajar (guru) dan pembelajar (siswa). Pengembangan $e$ learning dilembaga pendidikan bertujuan untuk meningkatkan efektivitas dan fleksibilitas pembelajaran.

E-learning dibeberapa sekolah pada umumnya berorientasi pada bentuk html (hypertext markup language) dan blog seperti wordpress yang belum mempunyai sistem pengelolaan pembelajaran. E-learning dimanfaatkan secara online dengan pengelolaan sistem pembelajaran dapat memanfaatkan LMS (Learning Management System). LMS adalah suatu perangkat lunak atau software untuk keperluan administrasi, dokumentasi, laporan sebuah kegiatan, kegiatan belajar mengajar dan kegiatan secara online dan materi-materi pelatihan. LMS dibentuk untuk membantu pengelola pembelajaran dalam melaksanakan perannya sebagai pendukung pembelajaran. Pemanfaatan e-learning menggunakan LMS diharapkan dapat membantu siswa dalam belajar. Guru juga dapat menciptakan kondisi pembelajaran secara terarah, sehingga dapat memudahkan dalam pengelolaanya.

Berdasarkan pengamatan dari media e-learning yang dikembangkan di beberapa instasi pendidikan, implementasi media e-learning: (1) media e-learning hanya berisi kumpulan bahan pelajaran yang disimpan di server; (2) pembelajaran $e$ learning hanya sekedar upload dan download materi; (3) fasilitas e-learning yang berupa: forum diskusi, chat, video, swf player, quiz $\mathrm{dsb}$, kurang optimal diimplementasikan pada pembelajaran.

Solusi untuk mengatasi permasalahan tersebut yaitu dengan menerapkan pendekatan teori kognitif multimedia pembelajaran dalam mengembangkan pembelajaran dengan menggunakan media $e$ learning. Pendekatan teori kognitif dalam media e-learning mencakup aspek penda- 
gogi dan teknologi. Menurut Richard E. Mayer (2009, p.64), teori kognitif multimedia pembelajaran adalah teori yang mendasari penggunaan media dalam pembelajaran. Teori kognitif multimedia pembelajaran memiliki 3 asumsi agar media yang dibuat efektif dan baik, asumsi tersebut yakni saluran ganda, kapasitas terbatas dan pemrosesan aktif. Perbedaan $e$ learning yang dikembangkan dengan teori kognitif multimedia pembelajaran dengan e-learning yang biasa adalah e-learning yang disajikan mengoptimalkan saluran ganda yang dimiliki manusia yaitu menggunakan audio-visual, materi pada e-learning didesain menggunakan teori kapasitas terbatas sehingga muatan materi tiap tampilan akan disesuaikan dengan kapasitas memori manusia, dan penataan struktur informasi yang baik akan membuat pemrosesan aktif lebih optimal karena siswa lebih aktif dalam pembelajaran.

Berdasarkan paparan latar belakang di atas, maka penulis akan melakukan penelitian dengan judul: Pengembangan E-learning dengan Pendekatan Teori Kognitif Multimedia Pembelajaran Pada Jurusan Teknik Komputer dan Jaringan di SMK Muhammadiyah 2 Yogyakarta. Kompetensi Dasar yang dikembangkan pada penelitian ini meliputi: Melakukan perbaikan/setting ulang PC, Melakukan perbaikan periferal, Melakukan perawatan PC, Melakukan instalasi sistem operasi berbasis GUI dan CLI, dan Melakukan instalasi software.

Tujuan penelitian ini adalah mengembangkan e-learning, mengetahui kelayakan e-learning, dan mengetahui keefektifan imple-mentasi e-learning dengan pendekatan teori kogntif multimedia pembelajaran pada jurusan teknik komputer dan jaringan yang dapat digunakan di SMK Muhammadiyah 2 Yogyakarta.

Fitur - fitur yang disajikan di elearning ini adalah: (1) komunikasi, meliputi: forum diskusi, file exchange, real time chat; (2) produktivitas, meliputi: kalender akademik, searching withing course; (3) administrasi, meliputi: student tracking dan manajemen user, kelas dan course; evaluasi, meliputi: assign-ment (tugas) dan kuis berupa soal multiple choice; dan multimedia, meliputi: multimedia interaktif (swf file) dan video simulasi.

E-learning yang dikembangkan menyajikan materi-materi pelajaran di program keahlian TKJ, namun isi materi dalam penelitian ini terbatas untuk kelas X. Adapun sajian dari e-learning adalah sebagai berikut.

Pertama, halaman depan, berisi banner yang memuat identitas e-learning, ucapan selamat datang, penjelasan umum tentang e-learning, fasilitas login, menu kategori pilihan kelas dan course, pengumuman dan kalender, dan informasi jam penunjuk waktu.

Kedua, ketika masuk kedalam course, maka halaman ini menyajikan: judul course, standar kompetensi dan kompetensi dasar course, silabus, glossary, resource learning, chatting, materi pembelajaran, chatting, assign-ment (siswa mengumpulkan tugas), quiz. Materi pembelajaran disajikan dalam bentuk: presentasi materi (ppt), modul belajar (pdf), simulasi materi (swf dan video).

Manfaat penelitian ini diharapkan menambah pengetahuan dan wawasan terutama menyangkut hal-hal yang berkaitan dengan pengembangan pembelajaran dengan e-learning. Manfaat bagi siswa yaitu: mempermudah dalam memahami materi pelajaran, menciptakan kondisi belajar yang kondusif, efektif dan fleksibel dan meningkatkan motivasi dalam belajar. Manfaat bagi guru yaitu: mempermudah proses penyampaian materi pelajaran, meningkatan kualitas pengajaran, dan mempermudah pengelolaan kegiatan belajar mengajar.

\section{Metode Penelitian}

Jenis Penelitian

Penelitian ini menggunakan pendekatan penelitian dan pengembangan atau Research and Development (R\&D). Penelitian dan pengembangan pendidikan adalah proses yang digunakan untuk mengembangkan dan menguji validasi atau 
kelayakan dari produk-produk yang dikembangkan.

Model pengembangan dalam ini bertujuan untuk mengembangkan dan menguji atau validasi kelayakan produk dari aspek pendidikan dan pembelajaran untuk meningkatkan dan mengembangkan mutu pendidikan dan pembelajaran secara efektif dan adaptabel.

Berdasarkan paparan diatas untuk mendapatkan produk yang sesuai dengan tujuan, maka penelitian pengembangan ini mengadaptasi model pengembangan $R \mathcal{E} D$ dari Alessi dan Trollip (2001, p.410) dan model desain pembelajaran Dick \& Carey (2005, pp.282-291).

\section{Waktu dan Tempat Penelitian}

Waktu penelitian adalah pada bulan April-Mei 2013. Tempat Penelitian di Sekolah Menengah Kejuruan Muhammadiyah 2 Yogyakarta Jurusan Teknik Komputer dan Jaringan.

Target/Subjek Penelitian

Subjek uji coba pada penelitian ini adalah siswa kelas $X$ jurusan Teknik Komputer dan Jaringan di SMK Muhammadiyah 2 Yogyakarta tahun pelajaran 2012/ 2013.

Prosedur

Penelitian ini menggunakan prosedur pengembangan yang merupakan kombinasi antara prosedur-prosedur pengembangan dari Alessi dan Trollip dan model desain pembelajaran Dick \& Carey.

Model Alessi Trollip merupakan model R\&D yang dirancang untuk pengembangan media secara komersial, terdapat beberapa komponen di model ini yang belum mengambarkan penilaian keefektifan media pembelajaran. Oleh karena itu maka penulis menggabungkan model Alessi Trollip dengan model Dick and Carey sebagai model pengembangan desain pembelajaran. Data, Intrumen, dan Teknik Pengumpulan Data. Adapun diagram prosedur penelitian ini disajikan pada Gambar 1.

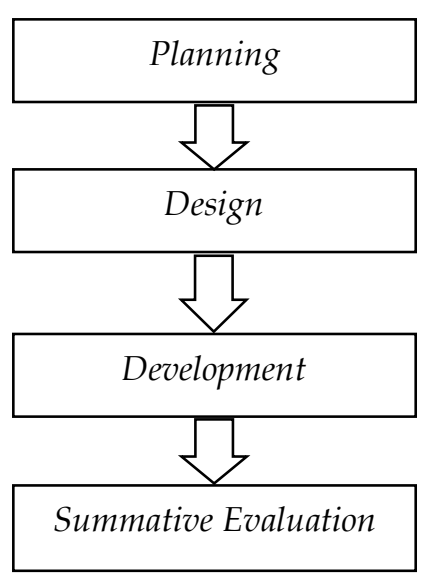

Gambar 1. Prosedur Penelitian

Prosedur pengembangan penelitian ini meliputi 4 tahap utama yaitu tahap planning, tahap design, tahap development dan tahap sumative evaluation. Adapun penjelasan dari masing-masing tahap adalah sebagai berikut:

\section{Tahap Planning}

Planning merupakan tahap perencanaan sebelum produk awal ditentukan dan dikembangkan. Pada tahap ini dilakukan beberapa hal yaitu: (a) studi pustaka; (b) studi lapangan; (c) menetukan topik; (d) menentukan standar kompetensi; (e) menentukan kompetensi dasar; (f) menyusun silabus; (g) menyusun rencana pelaksanaan pembelajaran.

\section{Tahap Design}

Design merupakan tahap pengembangan ide-ide, melakukan analisis konsep dan tugas, lakukan deskripsi program awal. Pada tahap ini dilakukan beberapa hal yaitu: (a) mengembangkan bahan pembelajaran; (b) membuat flowchart produk

\section{Tahap Development}

Development merupakan tahap kegiatan mengembangkan produk hingga validasi progam. Pada tahap ini kegiatan yang dilakukan adalah: (a) tahap produksi, memproduksi e-learning dengan merakit bagian-bagian berupa teks, grafis, audio, dan video ke dalam LMS Moodle; (b) tahap evaluasi formatif, evaluasi formatif ini dilakukan untuk mengetahui kelayakan 
produk e-learning yang dikembangkan. Tahap ini meliputi tes alfa dan tes beta. Tes alfa dilakukan oleh 2 ahli materi dan 2 ahli media, kemudian direvisi. Tes beta dilakukan oleh siswa sebagai user pengguna produk e-learning.

Pada setiap tahap pada planning, design, dan development, dilakukan on going evaluation atau evaluasi berkelanjutan yang dilakukan langsung dengan koreksi atau revisi bila terjadi kesalahan. Evaluasi ini bersifat tidak formal dan tidak menggunakan form yang terstruktur.

\section{Tahap Sumative Evaluation}

Sumative Evaluation merupakan tahap evaluasi untuk mengetahui keefektifan e-learning berdasarkan hasil belajar nilai kognitif. Sebelum e-learning diterapkan dik elas, maka langkah awal adalah melakukan pre-test, langkah selanjutnya adalah penerapan e-learning, kemudian melakukan post-test. Hasil dari uji coba tersebut digunakan untuk menentukan efektivitas $e$ learning yang dikembangkan.

\section{Teknik Pengumpulan Data}

Teknik pengumpulan data yang digunakan pada penelitian ini adalah dengan metode observasi, wawancara dan angket. Teknik ini dipakai untuk menjaring datadata selengkapnya yang berasal dari input, proses dan hasil. Penggunaan metode tersebut adalah:

\section{Wawancara}

Wawancara dilakukan secara terstruktur dan tidak terstruktur. Wawancara terstruktur menggunakan pedoman wawancara yang dipakai sebagai alat pengumpul data dari guru dan siswa sehubungan dengan analisis kebutuhan yang diperlukan untuk mengembangkan e-learning. Wawancara tidak terstruktur dilakukan untuk mengetahui saran, kritik, dan masukan-masukan yang bermanfaat bagi kualitas produk dari ahli media maupun ahli materi, pada saat uji validitas.

\section{Kuesioner}

Instrumen kuesioner digunakan untuk mendapatkan data tentang kelayakan kualitas e-learning yang dikembangkan berdasarkan aspek materi, aspek media sekaligus ahli pembelajaran, serta bagi siswa. Instrumen kuesioner disusun menggunakan skala Likert. Penyusunan kuesioner dilakukan berdasarkan kisi-kisi, setelah disusun kuesioner divalidasi oleh expert judgement untuk menjamin instrumen yang digunakan valid.

\section{Soal Tes}

Soal tes merupakan instrumen yang digunakan untuk mengetahui tingkat pemahaman siswa terhadap materi ajar setelah mereka belajar menggunakan media $e$ learning. Soal test berupa pre-test dan posttest.

Teknik Analisis Data

Data mengenai kualitas kelayakan dikumpulkan melalui kuesioner dan dianalisis dengan menggunakan statistik deskripstif dengan teknik presentase dan kategorisasi. Data dan saran yang diperoleh tersebut, dianalisis dan disimpulkan untuk perbaikan produk e-learning yang dibuat.

Teknik yang digunakan untuk memberikan kiteria nilai kelayakan produk yang dibuat, yaitu:

Data yang diperoleh dari kuesioner diubah dulu menjadi data interval sebagai berikut: sangat baik dengan skor 5, baik dengan skor 4, cukup baik dengan skor 3, kurang baik dengan skor 2, dan sangat kurang baik dengan skor 1. (Sukardjo, 2005, p.55).

Untuk mencari skor rata-rata dalam memberikan penilaian terhadap produk yang telah dikembangkan, maka peneliti menggunakan rumus:

$$
X i=\frac{\sum X}{n}
$$

Keterangan:

$$
\begin{array}{ll}
\mathrm{Xi} & =\text { Skor rata-rata } \\
\sum \mathrm{X} & =\text { Jumlah skor } \\
\mathrm{n} & =\text { Jumlah responden }
\end{array}
$$


Kriteria hasil penelitian dikategorikan sebagai berikut : $\mathrm{Xi}>4.2$ sangat baik, 3.4 $<\mathrm{Xi} \leq 4.2$ baik, $2.6<\mathrm{Xi} \leq 3.4$ cukup baik, $2.6<\mathrm{X}_{\mathrm{i}} \leq 3.4$ kurang baik, dan $\mathrm{Xi}_{\mathrm{i}} \leq 1.8$ sangat kurang baik.

Data tes menggambarkan keefektifan e-learning untuk pembelajaran dilihat dari aspek kognitif yaitu: seberapa besar presentase siswa yang telah mencapai nilai Kriteria Ketuntasan Minimal (KKM) dan nilai kebermaknaan belajar (effect size). Kriteria Ketuntasan Minimal (KKM) mata pelajaran Teknik Komputer dan Jaringan (TKJ) ditentukan sebesar 65. Penentuan KKM ini didasarkan pada kualitas input/ masukan, sarana/prasarana yang ada, dan tingkat kompleksitas materi. Jika siswa telah mencapai nilai minimal 65 artinya siswa tersebut telah tuntas.

Data tentang kebermaknaan belajar dianalisis dengan cara deskriptif yaitu dengan membandingkan antara skor pretest dan dengan hasil skor post-test. Menurut Olejnik dan Algina (2003) dalam Agung (2010, p.3) menyatakan bahwa effect size merupakan ukuran mengenai besarnya efek suatu variabel pada variabel lain, besarnya perbedaan maupun hubungan, yang bebas dari pengaruh besarnya sampel. Effect size juga dapat dianggap sebagai ukuran mengenai kebermaknaan hasil penelitian dalam tataran praktis. Rumus untuk mengetahui besarnya effect size adalah sebagai berikut:

$\mathrm{ES}=d=\overline{X_{2}}-\overline{X_{1}}$

Keterangan:

ES $=$ Effect Size

$\mathrm{d}=$ gain

$\overline{X_{1}}=$ Nilai rata-rata pre-test

$\overline{X_{2}}=$ Nilai rata-rata post-test

\section{Hasil Penelitian dan Pembahasan}

Deskripsi Produk

E-Learning yang dihasilkan dalam penelitian ini menggunakan sistem manajemen pembelajaran online dan di implementasikan dengan model blended learning.
E-learning dikembangkan dengan software moodle versi 2.4 yang dapat didownload dari http://www.moodle.org. LMS Moodle yang telah didownload kemudian diupload ke hosting yang sudah disiapkan, setelah proses upload selesai maka langkah selanjutnya adalah mengkonfigurasi informasi yang dibutuhkan dalam proses instalasi LMS Moodle dalam web hosting. Setelah itu, langkah selanjutnya adalah mendesain tampilan antarmuka (interface) berupa tema, banner, course yang tersedia, pengumuman, chatting, waktu, kalender, dan isi (content) materi pembelajaran.

E-learning yang dikembangkan, dapat diakses menggunakan browser dengan komputer/handphone yang terhubung internet dengan alamat: http://www.etkj. web.id. Pengguna e-learning ini dibagi ke dalam lima tingkatan, yaitu: administrator, course creator (pembuat mata pelajaran), teacher (guru), student (siswa) dan guest (tamu). Administrator memiliki kewenangan tertinggi karena dapat menyeting tampilan, mengangkat user untuk mendapatkan kewenangan sebagai course creator, teacher, dan student. Kewenangan siswa adalah dapat menggunakan semua fasilitas pembelajaran yang disajikan pada $e$ learning ini, sedangkan kewenangan guru adalah dapat mengelola pengelompokan dan penilaian untuk semua siswa pada mata pelajaran yang diampunya.

Deskripsi hasil pengembangan e-learning disajikan dengan tampilan screebshoot pada Gambar 1.

Tampilan awal e - learning ini adalah:

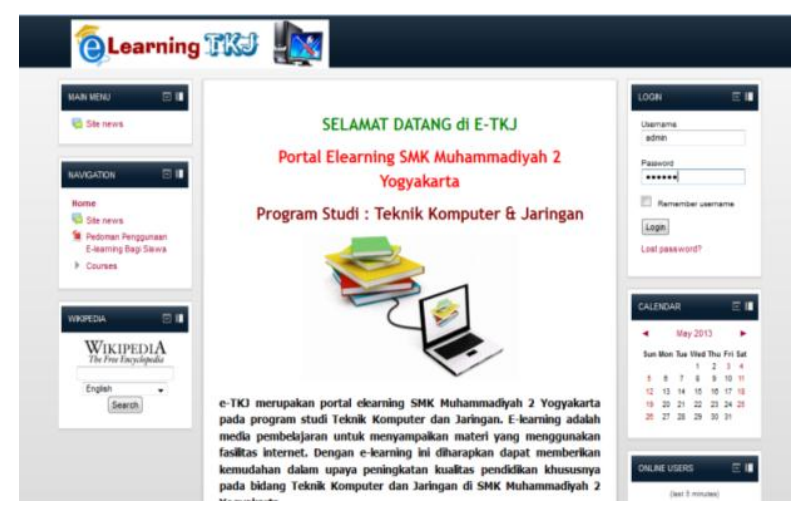

Gambar 1. Tampilan halaman awal 
Tampilan halaman course e-learning ini adalah:

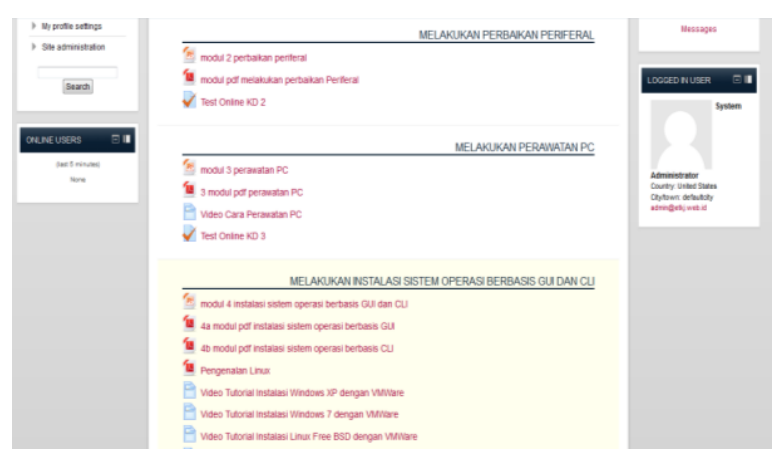

Gambar 2. Tampilan halaman course

Pengembangan e-learning dengan pendekatan teori kognitif dideskripsikan sebagai berikut :

\section{Saluran Ganda}

Manusia memiliki saluran terpisah untuk memproses informasi, yaitu mata dan telinga. Informasi disajikan ke mata melalui gambar, teks, ilustrasi, dan video sedangkan informasi yang disajikan lewat telinga berupa narasi dan suara-suara non verbal. Adapun penyajian asumsi saluran ganda dalam e-learning ini, salah satunya adalah pada video tutorial instalasi windows 7 dengan VMWare. Pada tutorial ini, informasi disajikan dengan menggunakan audio-visual disajikan pada Gambar 3.

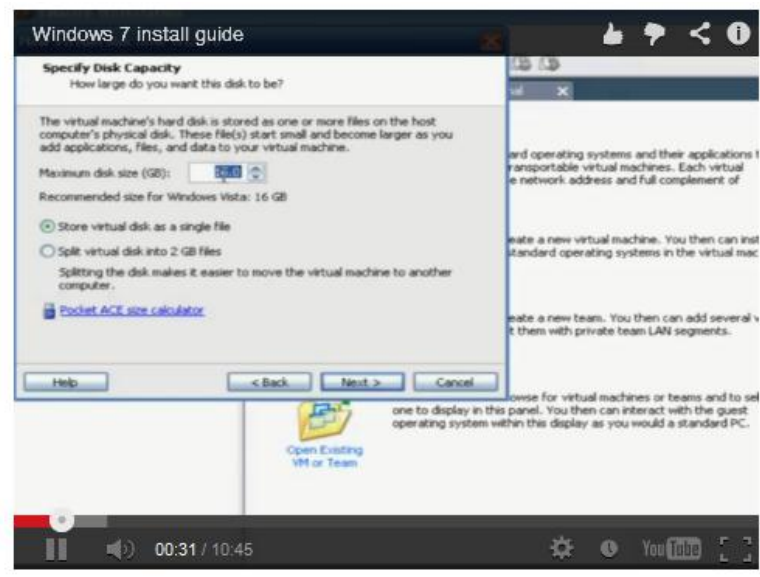

Gambar 3. Tampilan video tutorial instalasi windows 7 dengan VMWare

\section{Kapasitas Terbatas}

Manusia mempunyai keterbatasan atas jumlah informasi yang diproses dalam masing-masing saluran dalam waktu tertentu, sehingga muatan materi tiap tampil- an tidak akan melebihi kapasitas memori kerja manusia. Apenyajian asumsi kapasitas terbatas dalam e-learning ini, salah satunya adalah tampilan power point $e$ learning pada topik melakukan perbaikan periferal. Pada presentasi materi ini, informasi disajikan dengan menggunakan prinsip kapasitas terbatas, gambar dan tulisan disajikan secara berdekatan (prinsip contiguity) dan muatan tiap tampilan layar pada presentasi tidak berdesakan, sehingga memori kerja manusia tidak over load dalam memproses informasi yang masuk. Adapun contoh tampilan penerapan asumsi kapasitas terbatas disajikan pada Gambar 4.

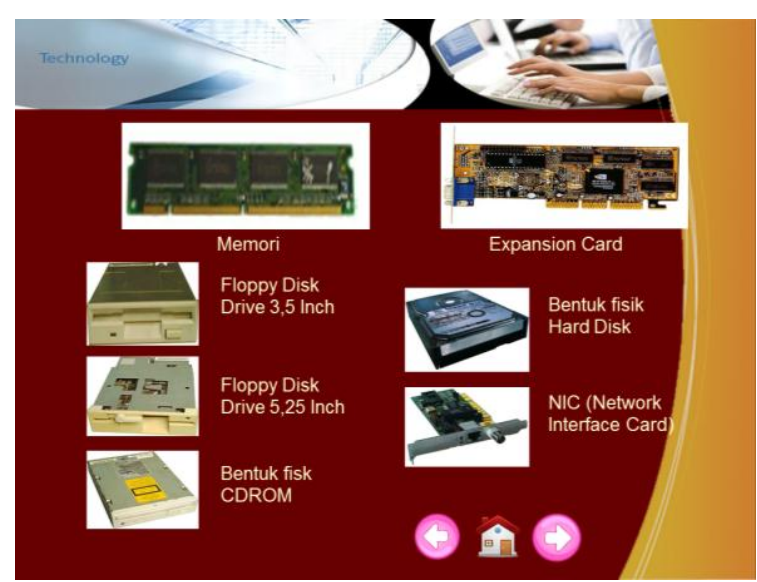

Gambar 4. Tampilan materi perbaikan periferal

\section{Pemrosesan Aktif}

Manusia secara aktif mengkonstruksi representasi mental yang saling terkait. Proses kognitif aktif yang dilakukan manusia adalah memberikan perhatian, menata informasi yang masuk, dan memadupadankan dengan pengetahuan lain. Penyajian asumsi pemrosesan aktif dalam e-learning ini, adalah: (1) tampilan navigasi pada tiap tampilan layar power point; (2) forum diskusi; dan (3) link sumber belajar yang relevan diluar e-learning. Penyajian media dengan menggunakan asumsi pemrosesan aktif akan membuat siswa aktif belajar, sehingga siswa mendapatkan pengalaman belajar dan mengkonstruksi sendiri pengetahuan yang diperolehnya. Adapun contoh tampilan penerapan asumsi pemrosesan aktif disajikan pada Gambar 5. 


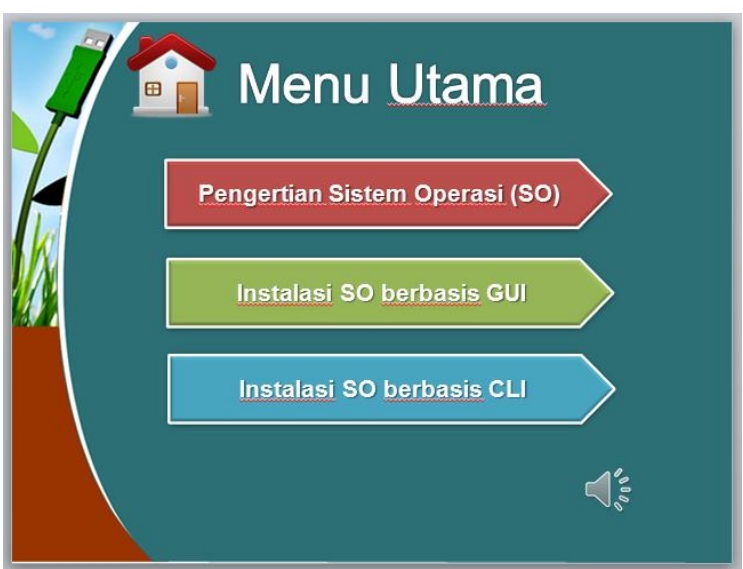

Gambar 5. Menu utama materi instalasi sistem operasis berbasis GUI dan CLI

Analisis Data

Hasil analisis data penelitian disajikan sebagai berikut:

\section{Analisis pengembangan e-learning}

Analisis data pada tahap ini meliputi data analisis kebutuhan pembelajaran tentang pengembangan e-learning. Data yang diperoleh berdasarkan analisis kebutuhan siswa diperoleh dari hasil kuesioner yang didapat sebelum media e-learning dikembangkan. Untuk memberikan gambaran jelas tentang hasil analisis kebutuhan dapat digambarkan pada grafik dibawah ini:

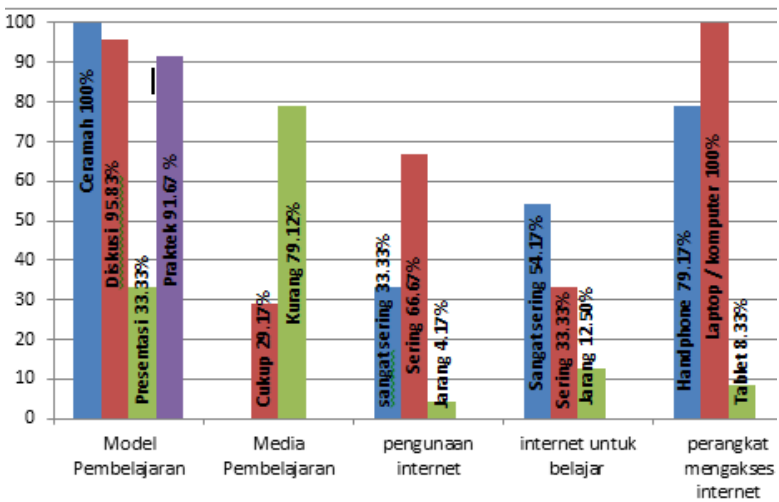

Gambar 6. Hasil analisis kebutuhan siswa

Analisis kelayakan e-learning

\section{Kelayakan media}

Validasi yang dilakukan oleh ahli media yaitu mencakup aspek media informasi e-learning yang dikembangkan. Ada- pun aspek tersebut meliputi: Appropriatness; Accuracy, Currency, dan Clarity; Screen Presentation and Design; dan teori kognitif multimedia pembelajaran. Validasi ahli media dilakukan oleh dua orang yaitu: Prof Dr Herminarto Sofyan, Mpd, beliau adalah dosen Program Pasca Sarjana Universitas Negeri Yogyakarta Jurusan Pendidikan Teknologi dan Kejuruan, dan Dr Haryanto, beliau adalah dosen Program Pasca Sarjana Universitas Negeri Yogyakarta Jurusan Teknologi Pembelajaran. Gambaran yang lebih jelas tentang kelayakan produk e-learning dari aspek media disajikan dalam diagram pada Gambar 7.

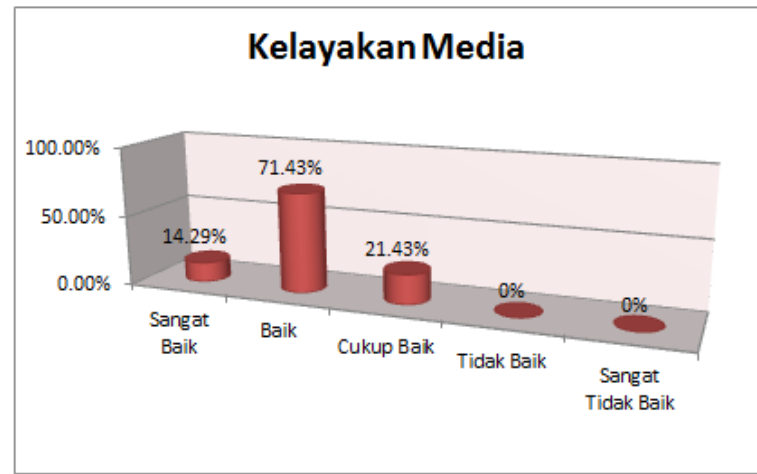

Gambar 7. Penilaian kualitas produk elearning dari aspek media.

Berdasarkan data tingkat persetujuan kelayakan media pada e-learning ini adalah $81.5: 21=3.88$. Berdasarkan kriteria yang telah ditetapkan termasuk dalam kategori Baik.

Secara kontinium dapat digambarkan seperti berikut:

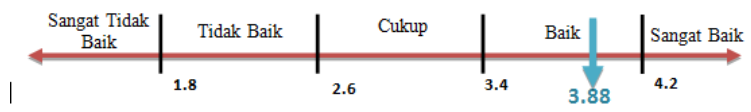

\section{Kelayakan materi}

Validasi yang dilakukan oleh ahli materi yaitu mencakup aspek media informasi e-learning yang dikembangkan. Adapun aspek tersebut meliputi: Appropriatness; Accuracy, Currency, dan Clarity; Screen Presentation and Design; dan teori kognitif multimedia pembelajaran. Validasi ahli materi dilakukan oleh dua orang yaitu: Adi 
Dewanto, M.Kom, beliau adalah dosen Fakultas Teknik Universitas Negeri Yogyakarta Jurusan Pendidikan Teknik Informatika, dan Bapak Suroji S.T, beliau adalah Ketua Program Studi Teknik Komputer dan Jaringan di SMK Muhammadiyah 2 Yogyakarta. Gambaran yang lebih jelas tentang kelayakan produk e-learning dari aspek materi dapat dilihat pada diagram Gambar 8.

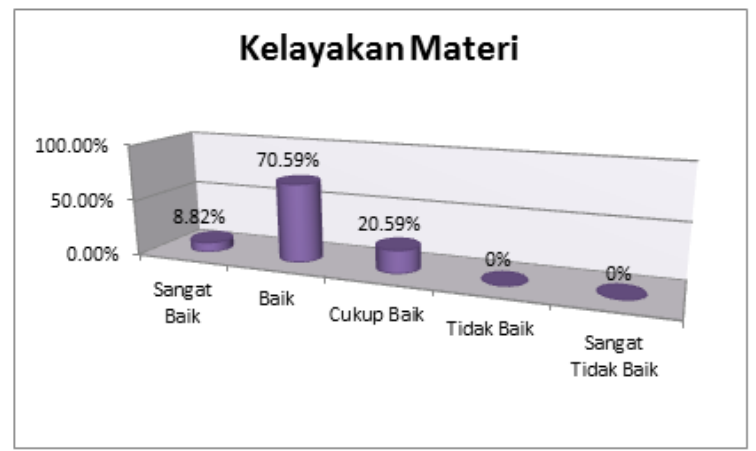

Gambar 8. Penilaian kualitas produk elearning dari aspek materi.

Berdasarkan data tingkat persetujuan kelayakan materi pada media pembelajaran adalah $66: 17=3.88$. Berdasarkan kriteria yang telah ditetapkan termasuk dalam katagori Baik.

Secara kontinium dapat digambarkan seperti berikut :

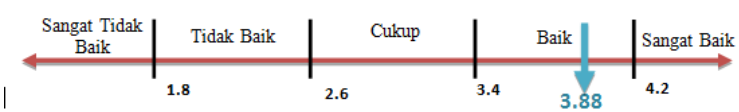

\section{Analisis keefektivan e-learning}

Untuk melihat efektivitas penggunaan e-learning dalam pembelajaran, maka dilakukan tes sumatif dengan memberikan pre-test dan pos-test pada siswa. Proses yang dilakukan untuk mengukur pencapaian kompetensi siswa secara berkelanjutan dalam proses pembelajaran, untuk mengetahui pemahaman siswa terhadap materi pembelajaran, memantau kemajuan, melakukan perbaikan pembelajaran, dan menentukan keberhasilan belajar siswa. Pencapaian kompetensi seorang siswa dapat dilihat dari keberhasilan siswa tersebut dalam mencapai nilai test.
Untuk mengetahui peningkatan hasil belajar siswa digunakan effect size. Effect size merupakan ukuran mengenai besarnya efek suatu variabel pada variabel lain, besarnya perbedaan maupun hubungan, yang bebas dari pengaruh besarnya sampel. Nilai ini menggambarkan perubahan pengetahuan siswa sebelum dan sesudah kegiatan pembelajaran, seperti pada Tabel 1.

Tabel 1. Nilai effect size hasil pre-test dan post-test

\begin{tabular}{cccc}
\hline & KD3 & KD 4,1 & KD 4,2 \\
\hline Rerata pre-test & 65,83 & 67,22 & 62,50 \\
Rerata Post-test & 76,11 & 74,17 & 69,17 \\
Effect Size & 10,28 & 6,94 & 6,67 \\
\hline
\end{tabular}

Tabel 1 menunjukkan adanya peningkatan pemahaman siswa pada materi KD 3, KD 4.1, dan KD 4.2. Dari ketiga effect size yang didapat, nilai tersebut positif, sehingga terdapat perubahan pengetahuan siswa yang lebih baik sesudah menggunakan e-learning sebagai media pembelajaran. Dari uji tersebut dapat dilihat bahwa terdapat perbedaan hasil pre-test dan post-test, sehingga dapat ditarik kesimpulan bahwa hasil belajar siswa dapat ditingkatkan secara signifikan dengan menggunakan media.

Untuk memberikan gambaran lebih jelas tentang hasil belajar siswa yang mengunakan e-learning dapat dilihat pada diagram Gambar 9.

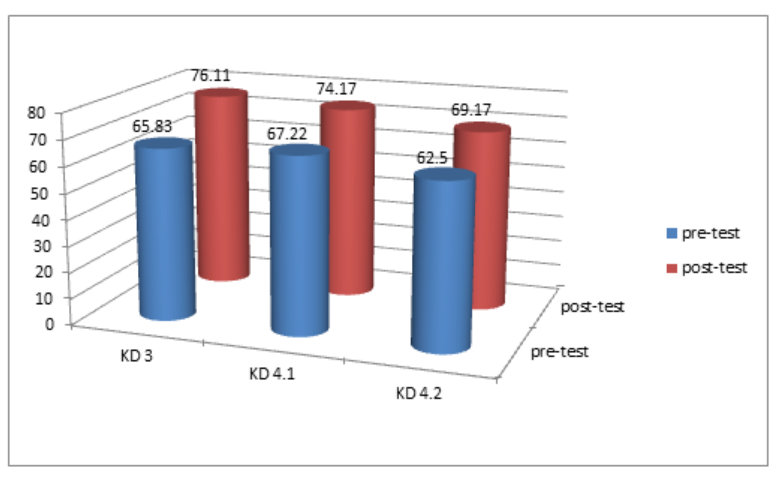

Gambar 9. Grafik Rerata nilai hasil pre-test dan post-test 


\section{Simpulan dan Saran}

Simpulan

Berdasarkan analisis data dan kajian produk akhir e-learning, dapat disimpulkan sebagai berikut.

Pertama, produk hasil pengembangan berupa e-learning yang merupakan model sistem pembelajaran (LMS) online yang dibuat dengan software aplikasi moodle versi 2.4 dengan alamat http://etkj.web.id. Implementasi produk e-learning dengan pendekatan teori kognitif multimedia pembelajaran ini terdiri atas beberapa komponen diantaranya: (1) halaman depan, terdiri atas: halaman pembuka, buku pedoman penggunaan e-learning untuk guru dan siswa, kalender akademik, kolom login, menu kelas, dan penunjuk waktu; (2) halaman course, terdiri atas: penjelasan muatan mata pelajaran, chatting, forum diskusi dan sajian presentasi materi. Sajian isi materi pada e-learning ini meliputi: Melakukan perbaikan dan/atau setting ulang sistem PC, Melakukan perbaikan peripherial, melakukan perawatan PC, melakukan instalasi sistem operasi berbasis graphical user interface (GUI) dan command line interface (CLI), dan Melakukan Instalasi Software. Materi-materi tersebut disajikan dalam format: presentasi power point, PDF, Flash dan video simulasi.

Kedua, kualitas e-learning dengan pendekatan multimedia pembelajaran dinyatakan "layak" untuk digunakan dalam pembelajaran. Hal ini berdasarkan pada rerata hasil penilaian ahli materi 3.88 (kategori baik), penilaian ahli media 3.88 (kategori baik), penilaian, dan penilaian respon siswa sebesar 3.34 (kategori baik).

Ketiga, keefektifan pembelajaran Teknik Komputer dan Jaringan dengan menggunakan media e-learning dengan pendekatan teori kognitif multimedia pembelajaran terbukti secara signifikan dapat meningkatkan hasil belajar siswa. Hal ini berdasarkan hasil rerata pretest: KD-3 65.83, KD-4.1 67.22, dan KD-4.2 62.50, dan hasil rerata post-test KD-3 76.11, KD-4.1 74.17, dan KD-4.2 69.17. Pencapaian ketuntasan belajar klasikal pada saat pre-test KD-3
$58.33 \%$ tuntas, KD-4.1 58.33\% tuntas, dan KD-4.2 54.17\%.

Keterbatasan Penelitian

Produk multimedia pembelajaran hasil pengembangan ini memiliki keterbatasan antara lain: (1) e-learning hanya mengembangkan materi Teknik Komputer dan Jaringan pada kelas $X$ semester 2 sehingga perlu pengembangan materi yang lebih kompleks; (2) instrumen evaluasi belum mampu mengukur indikator hasil belajar pada aspek psikomotor/kinerja, karena instrumen pengumpul data hanya menjaring data aspek kognitif hasil belajar mahasiswa; (3) e-learning dikembangkan dengan mengabaikan kecepatan akses provider server hosting.

\section{Saran}

Berdasarkan kesimpulan dan keterbatasan penulis dalam penelitian ini, maka peneliti sarankan: (1) untuk pengembangan lebih lanjut sebaiknya ditambahkan materi mata pelajaran yang belum tercakup $\mathrm{d}$ idalam e-learning, tidak hanya terbatas satu semester; (2) waktu pembelajaran e-learning dapat dilakukan diluar jam pelajaran agar lebih flexibel dan memperoleh akses internet yang lebih cepat; (3) program e-learning ini sesuai dengan prinsip-prinsip desain pembelajaran dan sesuai dengan silabus dan RPP pembelajaran mata pelajaran multimedia, maka para pendidik khususnya guru diharapkan dapat menggunakan produk ini untuk pembelajaran; (4) produk yang dikembangkan ini masih terbatas pada pemberian suplemen atau sumber informasi bagi siswa. Pengembangan $e$ learning lebih lanjut bisa diharapkan tidak hanya sebagai sarana dan sumber belajar, namun menjawab tantangan pembelajar dan kemajuan zaman serta melakukan kerja sama di antara beberapa sekolah. Sehingga komunikasi dan transfer ilmu dapat kita share melalui e-learning.

\section{Daftar Pustaka}

Agung Santoso. (2010). Studi deskriptif effect size penelitian-penelitian di 
fakultas psikologi universitas sanata dharma. Jurnal Penelitian Sanata Dharma, (50) 1-17.

Alessi \& Trollip. (2004). Multimedia for learning: methods and development (3th ed.). Massachusetts : Ally \& Bacon A Pearson Education Company.

Clark, Ruth Calvin \& Richard Mayer. (2008). E-learning and the science of instruction. San Fransisco: Pfeiffer

Dick \& Carey. (2005) The systematic design of instruction. (6 $6^{\text {th }}$ ed). Boston : Scott, Pearson. A.B
Herman Dwi Sudjono, (2010). Membangun course elearning berbasis moodle. Yogyakarta: UNY Press.

Mayer, R.E. (2007). Multimedia learning. New York: Cambridge University Press.

Sugiyono, Prof. Dr. (2007). Statistika untuk penelitian. Bandung : CV. Alfabeta

Sukardjo. (2006). Desain pembelajaran: evaluasi pembelajaran. Handout Perkuliahan: PPs UNY. 